Table 3. Independent predictors of US detected inflammatory findings

\begin{tabular}{lllll}
\hline & $\mathrm{p}$ & Odds ratio & \multicolumn{2}{c}{$95 \%$ C.I. } \\
\hline & & & Lower & Upper \\
\hline ESR (mm/h) & 0.039 & 1.04 & 1.002 & 1.078 \\
Time (months) from symptoms onset & 0.1 & 0.924 & 0.841 & 1.015 \\
\hline
\end{tabular}

\begin{tabular}{|c|c|c|c|c|c|}
\hline & & $\begin{array}{l}\text { Total } \\
n=57\end{array}$ & $\begin{array}{l}\text { US inflammaterx } \\
\text { findings. } \\
n=20\end{array}$ & $\begin{array}{c}\text { NouULS inflammatory } \\
\text { findings } \\
n=37\end{array}$ & p \\
\hline Age & & $55.8 \pm 15.2$ & $53.9 \pm 14.5$ & $59.5 \pm 16.2$ & 0.2 \\
\hline Sex & Eeprals & $41(71.9 \%)$ & $13(65 \%)$ & $28(75.7 \%)$ & 0.3 \\
\hline \multirow{3}{*}{$\begin{array}{l}\text { Smoking } \\
\mathrm{n}=52\end{array}$} & Non smeleer & $27(47.4 \%)$ & $10(55.6 \%)$ & $17(50 \%)$ & \multirow{3}{*}{0.8} \\
\hline & Strober & $20(35.1 \%)$ & $6(33.6 \%)$ & $14(41.2 \%)$ & \\
\hline & Earmear & $5(8.8 \%)$ & $2(11.1 \%)$ & $3(8.8 \%)$ & \\
\hline \multirow{3}{*}{ Extension } & Mlonoarticulas & $7(12.3 \%)$ & $3(15 \%)$ & $4(10.8 \%)$ & \multirow{3}{*}{0.9} \\
\hline & Qlierearticulas & $8(14 \%)$ & $5(25 \%)$ & $3(8.1 \%)$ & \\
\hline & Belvarticular & $42(73.7 \%)$ & $12(60 \%)$ & $30(81.1 \%)$ & \\
\hline \multicolumn{2}{|c|}{$\begin{array}{l}\text { Time (months) } \\
\text { from symptoms onset }\end{array}$} & $11.4 \pm 10.4$ & $7.3 \pm 6.2$ & $13.5 \pm 11.5$ & 0.049 \\
\hline \multicolumn{2}{|c|}{$\begin{array}{l}\text { from symptoms onset } \\
\text { ESR }(\mathrm{mm} / \mathrm{h})\end{array}$} & $19.1 \pm 21$ & & & 0.044 \\
\hline \multirow{2}{*}{\multicolumn{2}{|c|}{$\begin{array}{l}\operatorname{CRP}(\mathrm{mg} / \mathrm{dL}) \mathrm{n}=47 \\
\mathrm{RF}(\mathrm{dU} / \mathrm{mL}) \mathrm{n}=53\end{array}$}} & $0.6=1.4$ & $1.1 \pm 1.9$ & $0.4 \pm 0.9$ & 0.15 \\
\hline \multirow{2}{*}{\multicolumn{2}{|c|}{$\begin{array}{l}\mathrm{RF}(\mathrm{IU} / \mathrm{mL}) \mathrm{n}=53 \\
\mathrm{CCP}(\mathrm{IU} / \mathrm{mL})\end{array}$}} & $64.3 \pm 321.6$ & $21 \pm 53.7$ & $88.5 \pm 399.7$ & 0.5 \\
\hline & & $522=2314$ & $1048 \pm 3605$ & $223+1036$ & 02 \\
\hline
\end{tabular}

Conclusion: PD US inflammatory findings are found in 1 over 3 patients with IA being PD synovitis the most common finding, specially at the wrists and MCP joints. Higher ESR values were significantly associated with the presence of US inflammatory findings. Our data highlights how the use of PD US may be useful to detect subclinical synovitis in patients with IA.

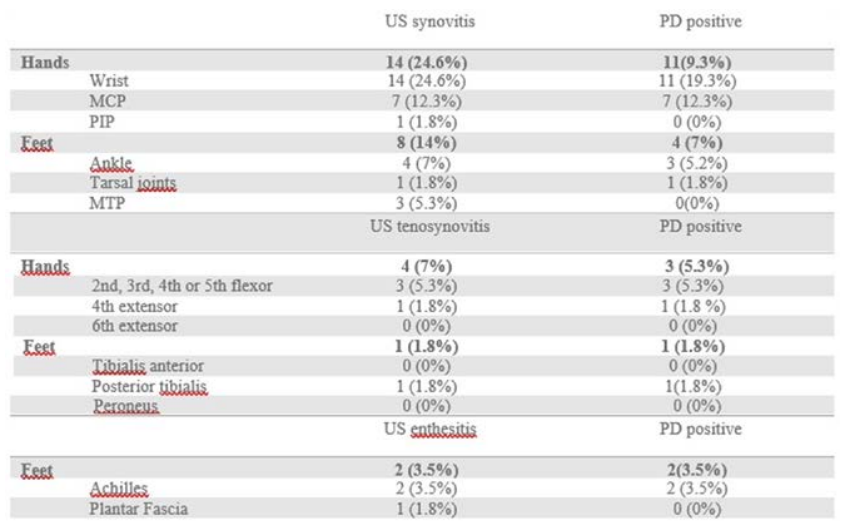

Table 2. US findings of patients with IA

Disclosure of Interests: Katerine López Gloria: None declared, Isabel Castrejon: None declared, Laura Trives Folguera Speakers bureau: ROCHE, Juan Carlos Nieto Speakers bureau: Pfizer, Abbvie, MSD, Novartis, Janssen, Lilly, Nordic Pharma, BMS, Gebro, FAES Farma, Roche, Sanofi, Belén Serrano Benavente: None declared, Julia Martínez-Barrio Consultant of: UCB Pharma, Javier Rivera: None declared, Carlos Gonzalez Consultant of: Gilead, Janssen, Novartis,., Speakers bureau: Abbvie, Celgene, Gilead, Janssen, Novartis, Pfizer, Roche, Indalecio Monteagudo: None declared, Jose-Maria Alvaro-Gracia Grant/research support from: Abbvie, Elli-Lilly, MSD, Novartis, Pfizer, Consultant of: Abbvie, BMS, Janssen-Cilag, Elli-Lilly, MSD, Novartis, Pfizer, Sanofi, Tigenix, Roche, UCB, Paid instructor for: ElliLilly, Pfizer, Roche, Speakers bureau: Abbvie, BMS, Janssen-Cilag, Elli-Lilly, Gedeon Richter, MSD, Novartis, Pfizer, Sanofi, Tigenix, Roche, UCB, Juan Molina Collada: None declared

DOI: 10.1136/annrheumdis-2020-eular.6332

\section{AB0206 $\quad$ CIRCULATING CENTROMERE PROTEIN F AUTOANTIBODIES FOR PREDICTING CLINICAL RESPONSE TO INFLIXIMAB IN RHEUMATOID ARTHRITIS}

L. Lourido $^{1,2}$, C. Ruiz-Romero ${ }^{1,3}$, F. Picchi ${ }^{1}$, N. Diz-Rosales ${ }^{1}$, S. VilaboaGalán ${ }^{1}$, C. Fernández-López ${ }^{1}$, J. A. Pinto Tasende ${ }^{1}$, E. Perez-Pampin ${ }^{4}$, C. Regueiro Expósito ${ }^{4}$, A. Mera Varela ${ }^{4}$, A. Gonzalez ${ }^{4}$, K. Hambardzumyan ${ }^{5}$, S. Saevarsdottir ${ }^{5}$, P. Nilsson ${ }^{6}$, F. J. Blanco ${ }^{1,2} .^{1}$ Grupo de Investigación de Reumatología (GIR), Instituto de Investigación Biomédica de A Coruña (INIBIC), Complexo Hospitalario Universitario de A Coruña (CHUAC), Sergas. Universidade da Coruña (UDC). As Xubias, ${ }^{15006}$. A Coruña, Spain., A Coruña, Spain; ${ }^{2}$ RIER-RED de Inflamación y Enfermedades
Reumáticas, Spain, Madrid, Spain; ${ }^{3}$ CIBER-BBN Instituto de Salud Carlos III, Spain, Madrid, Spain; ${ }^{4}$ Laboratorio Investigacion ${ }^{10}$ and Rheumatology Unit, Instituto de Investigacion Sanitaria-Hospital Clinico Universitario de Santiago, Santiago de Compostela, Spain, Santiago de Compostela, Spain; ${ }^{5}$ Unit of Rheumatology, Department of Medicine, Karolinska Institutet and Rheumatology Clinic, Karolinska University Hospital, Stockholm, Sweden, Stockholm, Sweden; ${ }^{6}$ Division of Affinity Proteomics, Department of Protein Science, KTH Royal Institute of Technology, SciLifeLab, Stockholm, Sweden, Stockholm, Sweden

Background: One third of patients with rheumatoid arthritis (RA) respond poorly to TNF inhibitors and related studies are inconsistent in predictive biomarkers. The identification of biomarkers that predict the treatment response prior to drug exposure is a current priority on the RA field. ACPA and RF are ubiquitously tested in RA patients, but other autoantibodies exist and may provide additional information on RA treatment response.

Objectives: This study aimed to identify circulating autoantibodies for predicting response to infliximab (IFX) in RA.

Methods: We profiled the autoantibody repertoire of baseline sera from 155 biologic naïve RA patients treated with IFX. The sera were provided by three independent clinical sources and distributed in one exploratory cohort $(\mathrm{N}=20)$ collected from Hospital Clínico Universitario of Santiago de Compostela (Spain), one replication cohort $(\mathrm{N}=61)$ collected from Hospital Universitario de A Coruña (Spain) and samples from the Swedish Farmacotherapy (SWEFOT) trial (Sweden) $(\mathrm{N}=74)$ for clinical validation. The presence of autoantibodies and their levels in serum were analysed in association with EULAR clinical response at 6 months follow-up: good response $(\mathrm{GR}, \mathrm{N}=56)$, moderate $(\mathrm{MR}, \mathrm{N}=55)$ and non-response ( $N R, N=44)$. A suspension bead array platform built on protein fragments within Human Protein Atlas and selected from an initial untargeted screening using an array containing 42000 antigens was employed to identify the $\lg G$ and $\operatorname{IgA}$ autoantibodies on the exploratory cohort. A replication and validation phases were carried out on the other two serum sample cohorts. Meta-analysis and Receiver Operating Curves were performed in order to assess the clinical relevance of the findings observed.

Results: Meta-analysis revealed that the levels in serum of IgG autoantibodies against Centromere protein F (CENPF) are significantly increased in responders (good responders and moderate responders; $\mathrm{N}=111$ ) to IFX compared to non-responders $(\mathrm{N}=44)(\mathrm{P}=0.018)$. CENP-F is a proliferation-associated and cell cycle-dependent centromere autoantigen that might be involved in the increased or abnormal cell proliferation that occurs during RA process. The combination of the anti-CENPF antibodies with clinical variables (age, sex, DAS28-ESR) resulted in the best model to discriminate the patients that will respond to IFX, showing an AUC of $0.756(95 \% \mathrm{Cl}[0.639$ 0.874], $P=0.001$ ).

Conclusion: High serum levels of IgG anti-CENPF antibodies might be potentially useful to identify RA patients more likely to benefit from IFX

Disclosure of Interests: Lucía Lourido: None declared, Cristina Ruiz-Romero: None declared, flor picchi: None declared, Naomi Diz-Rosales: None declared, Sergio Vilaboa-Galán: None declared, Carlos Fernández-López: None declared, Jose Antonio Pinto Tasende: None declared, Eva Perez-Pampin: None declared, Cristina Regueiro Expósito: None declared, ANTONIO MERA VARELA: None declared, Antonio Gonzalez: None declared, Karen Hambardzumyan: None declared, Saedis Saevarsdottir Employee of: Part-time at deCODE Genetics/Amgen Inc, working on genetic research unrelated to this project, Peter Nilsson: None declared, Francisco J. Blanco Grant/research support from: Sanofi-Aventis, Lilly, Bristol MS, Amgen, Pfizer, Abbvie, TRB Chemedica International, Glaxo SmithKline, Archigen Biotech Limited, Novartis, Nichi-iko pharmaceutical Co, Genentech, Jannsen Research \& Development, UCB Biopharma, Centrexion Theurapeutics, Celgene, Roche, Regeneron Pharmaceuticals Inc, Biohope, Corbus Pharmaceutical, Tedec Meiji Pharma Kiniksa Pharmaceuticals, Ltd, Gilead Sciences Inc, Consultant of: Lilly, Bristol MS, Pfizer

DOI: 10.1136/annrheumdis-2020-eular.4869

\section{AB0207 CLINICAL IMPACT OF ANTI-CARP ANTIBODIES IN RHEUMATOID ARTHRITIS}

M. Markovic ${ }^{1}$, B. Glisic ${ }^{2}$, M. Petronijevic ${ }^{2}{ }^{1}$ Clinical Center of Montenegro, Clinic of Internal Medicine, Rheumatology Department, Podgorica, Montenegro;

${ }^{2}$ Military Medical Academy, Clinic of Rheumatology, Belgrade, Serbia

Background: Antibodies directed against carbamylated proteins (anti-CarP) have been recently introduced for the first time as a new biomarker in rheumatoid arthritis (RA) (1). Their presence is predictive for the development of RA (2). Anti-CarP antibodies are associated with the development of more severe forms of the disease in overall and anti-citrullinated peptide antibodies negative 
population of patients with RA (3). In the literature is still current the research which associate these antibodies with disease activity and functional status of patients.

Objectives: This study investigated the incidence of anti-CarP positive findings in patients with RA on synthetic and biologic disease-modifying therapy (DMT) and the relationship between anti-CarP antibody status and both disability and disease activity.

Methods: It was an open-label, observational, cross-sectional study. The trial included 70 patients with RA diagnosed on the basis of ACR 1987 and ACR / EULAR 2010 criteria, on treatment with synthetic and biological DMT, who attended the Clinic of Rheumatology, Military Medical Academy, from September to December 2018. The control group consisted of 18 healthy individuals. After approval of the institutional Ethical Committee and after patients have signed Informed Consent,the study was conducted. Disease activity score (DAS28) was determined for the assessment of RA activity, and the assessment of patients' functional ability was performed using the Health assessment questionnaire disability index (HAQ-DI). Concentration of anti-CarP antibodies was determined by commercial ELISA anti-CarP quantitative sandwich immunoassay. The methods of descriptive and analytical statistics were used in statistical data processing.

Results: Based on the cut-off value $(5.9 \mathrm{ng} / \mathrm{ml})$, no one in the control group had positive anti-CarP antibodies, while $34.7 \%$ of the subjects with RA were positive. The positive correlation was found between anti-CarP antibody concentration and DAS28 in all RA patients $(p=0.0003$; Pearson $r$ $=0.4829$ ). The positive correlation was also found between anti-CarP antibody concentration and HAQ-DI in all RA patients $(p=0.0003$; Pearson $r$ $=0.4253$ )

Conclusion: Anti-CarP antibodies were present in a significant number of patients with RA. This study demonstrated that patients with RA with higher concentrations of anti-CarP antibodies have higher disease activity and impaired functional status. It is undisputed that further and larger studies are needed to better determine the clinical significance of these antibodies.

References:

[1] Shi J, Knevel $\mathrm{R}$ et al. Autoantibodies recognizing carbamylated proteins are present in sera of patients with rheumatoid arthritis and predict joint damage. Proc Natl AcadSci U S A. 2011 Oct 18;108(42):17372-7.

[2] Yee A, Webb T et al. Anti-CarP antibodies as promising marker to measure joint damage and disease activity in patients with rheumatoid arthritis. Immunol Res. 2015 Feb;61(1-2):24-30.

[3] Brink M, Verheul MK et al. Anti-carbamylated protein antibodies in thepresymptomatic phase of rheumatoid arthritis, their relationship with multiple anticitrulline peptide antibodies and association with radiological damage. Arthritis Res Ther. 2015 Feb 7:17:25.

Graphs 1 and 2. Correlation of anti-CarP antibody concentration with DAS28 and HAQ-DI in all RA patients

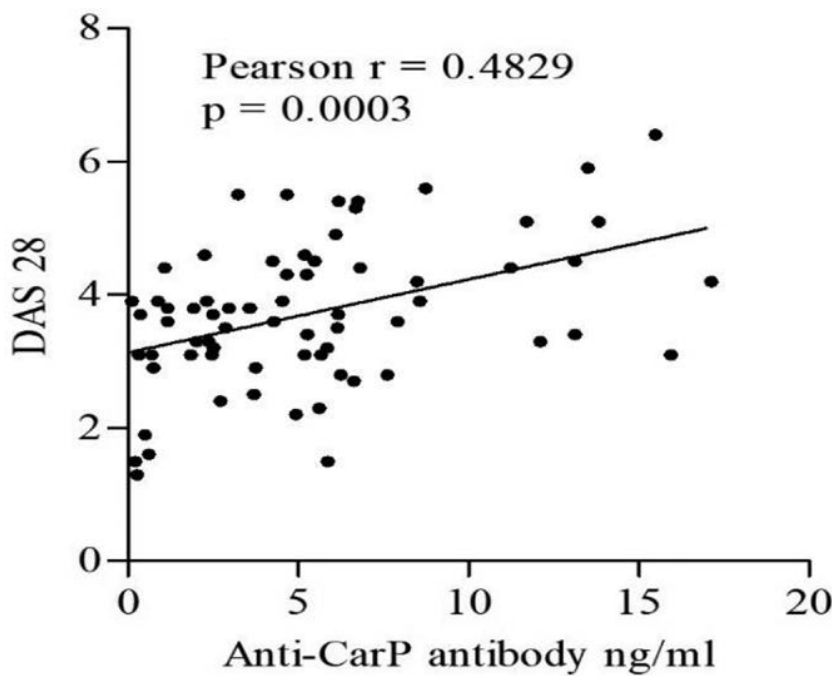

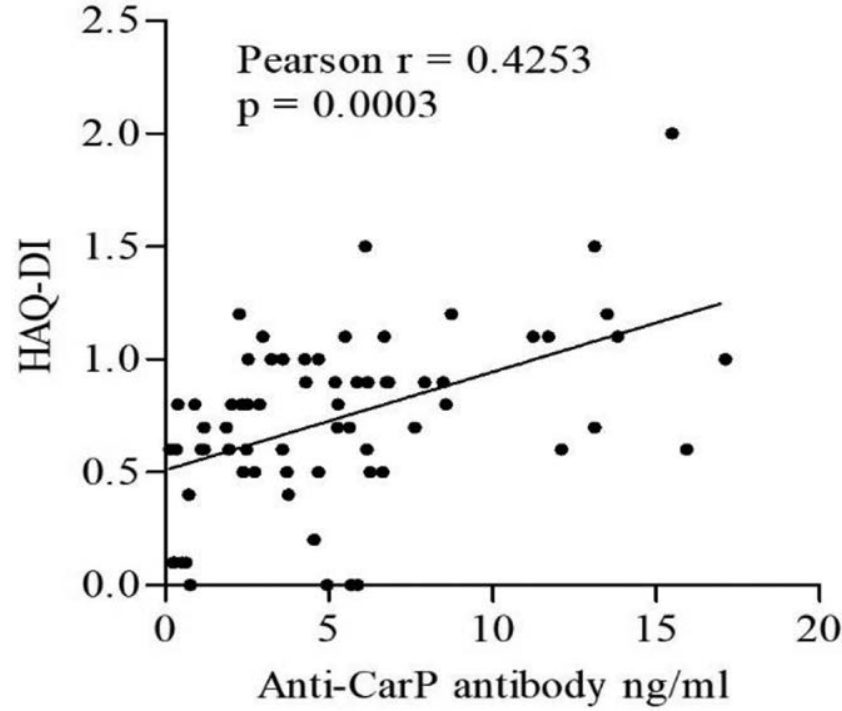

Disclosure of Interests: None declared

DOI: 10.1136/annrheumdis-2020-eular.4110

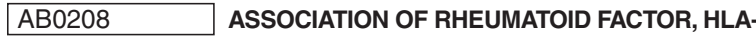 DRB1 SHARED EPITOPE (SE) AND SMOKING WITH RADIOGRAPHIC OUTCOME IN RHEUMATOID ARTHRITIS}

E. Mole ${ }^{1}$, A. Tarassi ${ }^{2}$, A. Tzioufas ${ }^{3}$, M. N. Manoussakis ${ }^{3}$, A. Tsirogianni ${ }^{2}$, T. Athanassiades ${ }^{2}$, V. Kitsiou ${ }^{2}$, S. Gazi ${ }^{1}$, P. Vlachoyiannopoulos ${ }^{3}$. 1"KAT" General Hospital of Attica, Department of Rheumatology, Athens, Greece; ${ }^{2}$ Evangelismos Hospital, Immunology - Histocompatibility Department, Athens, Greece; ${ }^{3}$ University of Athens School of Medicine, Department of Pathophysiology, Athens, Greece

Background: Genetic and environmental factors interact in aetiopathogenesis of Rheumatoid Arthritis (RA). However, it remains unclear whether curren smoking, presence of Rheumatoid factor (RF) and HLA-DRB1 SE influence the radiographic outcome.

Objectives: To clarify the possible associations between radiographic outcome, HLA-DRB1 SE, RF and smoking status in patients with longstanding RA.

Methods: An observational study of 240 consecutive Greek patients with RA, whose mean age and mean disease duration was $65.31 \pm 12.5$ and $12.7 \pm 11.8$ years respectively. Among them $74.17 \%$ were female, $40 \%$ were smokers, $60.42 \%$ had positive RF and $68.33 \%$ possessed at least one SE allele. HLADRB1 alleles were typed by molecular techniques (PCR-SSOP and SSP). X-rays of hands and feet were performed and scored by the Sharp-van der Hejde score (SHS) method.

Results: Results were stratified by RF and smoking status and analyzed by multivariate logistic regression. Overall, the mean SHS was significantly higher in RF positive than RF negative patients and in smokers than non-smokers $(52.76 \pm 31.1$ vs $38.4 \pm 31.96$, p: $0.0007,55.33 \pm 38.56$ vs $26.8 \pm 22.32$, $p<0.0001$, respectively). Furthermore, patients that possessed at least one SE allele had higher SHS than SE negative (35.49 \pm 24.76 vs $25.74 \pm 19.22$, p: 0.0013$)$. An association between radiographic severity and SE was found in RF positive patients. More specifically, seropositive patients carrying at least one SE allele had higher SHS than those lacking SE $(40.85 \pm 33.21$ vs $29.23 \pm 24.72$, p: 0.037$)$. On the other hand, smokers with at least one SE allele had higher SHS when compared to smokers without SE (29.27 \pm 25.20 vs $20 \pm 17.22$, p: 0.048$)$. Among RF negative and non-smokers RA patients, no significant association was found between the presence of HLADRB1 SE and radiographic severity.

Conclusion: Our data indicate that in longstanding RA there is an association between RF positivity, the presence of SE, current smoking status and radiographic outcome.

Disclosure of Interests: None declared

DOI: 10.1136/annrheumdis-2020-eular.4931 